\title{
PENGARUH LEVERAGE, PROFITABILITAS DAN COMPANY SIZE TERHADAP PENGUNGKAPAN CORPORATE SOCIAL RESPONSIBILITY PADA PERUSAHAAN FOOD AND BEVERAGES YANG TERDAFTAR DI BEI (2016-2018)
}

\author{
*Alfia Rizqi Aprillia, Arief Rahman, Kusni Hidayati \\ Jurusan Akuntansi Fakultas Ekonomi dan Bisnis \\ Universitas Bhayangkara Surabaya, Indonesia
}

DOI: 10.46821/equity.v1i1.6

\begin{abstract}
ABSTRAK
Penelitian ini bertujuan untuk menguji pengaruh rasio leverage, profitabilitas dan company size terhadap pengungkapan CSR secara simultan dan parsial pada perusahaan Food and Beverages yang terdaftar di BEI periode tahun 2016-2018. Sampel penelitian dipilih dengan menggunakan teknik purposive sampling sehingga didapatkan 16 perusahaan (48 firm year). Teknik analisis yang digunakan adalah uji asumsi klasik yang terdiri dari uji normalitas, uji multikolonieritas, uji autokorelasi. Pengujian hipotesis menggunakan uji $F$ dan uji t. Berdasarkan hasil analisis dan pembahasan dapat disimpulkan bahwa secara parsial leverage berpengaruh signifikan terhadap pengungkapan CSR. Sedangkan profitabilitas dan company size secara parsial tidak berpengaruh signifikan terhadap pengungkapan CSR. Hasil uji $F$ menunjukkan bahwa leverage, profitabilitas dan company size berpengaruh secara simultan terhadap pengungkapan CSR.
\end{abstract}

Kata kunci: Leverage, Profitabilitas, Company Size, dan Pengungkapan Corporate Social Responsibility (CSR).

\begin{abstract}
The purpose of this research is to find out the influence of leverage, profitabilitas, and company size to CSR simultaneously and partial in the Food and Beverages company listed on the BEI 2016-2018. The research sample has been selected by using purposive sampling technique therefore 16 Food and Beverages companies (48 firm year). Analysis technique used was classical assumption test constinting of normality test, multicollinerarity test, autocorrelation test. Hypothesis testing used $F$ test and t test. Based on analysis result and discussion it partially leverage has a significant effect on CSR. However, partially profitability and company size have no significant effect on CSR. F test result indicated that leverage, profitability and company size simultaneously had significant effect on CSR.
\end{abstract}

Keywords: Leverage, Profitabilitas, Company Size, and Corporate Social Responsibility (CSR) Disclosure 
PENDAHULUAN

Di era saat ini, persaingan dalam dunia bisnis semakin ketat. Persaingan tidak hanya dalam satu sektor industri, melainkan juga terjadi dalam berbagai sektor industri. Sektor Industri Food and Beverages adalah perusahaan yang bergerak di bidang makanan dan minuman. Di Indonesia perusahaan makanan dan minuman dapat berkembang pesat, hal ini terlihat dari jumlah perusahaan yang terdaftar di Bursa Efek Indonesia dari periode ke periode semakin banyak. Penelitian ini menggunakan perusahaan Food and Beverages sebagai penelitian karena saham yang berasal dari produk makanan dan minuman merupakan saham yang paling tahan krisis ekonomi disbanding sekto lain karena dalam kondisi krisis atau tidak, sebagian besar produk makanan dan minuman tetap dibutuhkan. Karena saat ini perusahaan tidak hany dituntut mencari keuntungan atau laba semata tetapi juga harus mempraktikkan tanggung jawab sosial masyarakat yang kita kenal dengan istilah Corporate Social Responsibility. CSR merupakan tanggung jawab moral perusahaan terhadap para strategic-stakeholdernya, terutama komunitas atau masyarakat sekitar wilayah kerja dan operasinya, karena tanpa diwajibkan perusahaan akan dengan sendirinya membuat laporan kepada stakeholder karena perusahaan tersebut akan mendapat sanksi dari stakeholder bila tidak membuat laporan. Perusahaan sebagai bagian dari masyarakat dan lingkungan perlu menyaari bahwa keberhasilan yang dicapai bukan hanya dipengaruhi oleh faktor internal melainkan juga dipengaruh oleh masyarakat dan lingkungan atau komunitas di sekitar perusahaan (Rahman, 2009).

\section{LANDASAN TEORI}

\section{Teori Stakeholder}

Stakeholder merupakan semua pihak baik internal maupun eksternal yang mempunyai hubungan yang bersifat mempengaruhi maupun dipengaruhi. Stakeholder theory berpendapat bahwa perusahaan bukanlah entitas yang hany beroperasi untuk kepentingannya sendiri, namun memberikan manfaat bagi stakeholder (Ghozali dan Chariri, 2007). Stakeholder merupakan pihak-pihak yang berkepentingan terhadap perusahaan yang meliputi karyawan, konsumen, masyarakat, pemerintah, pemegang saham, kreditur dan lain-lain. terdapat sejumlah stakeholder yang ada di masyarakat, dengan adanya pengungkapan CSR merupakan cara untuk mengelola hubungan dengan organisasi kelompok stakeholder yang berbeda. Pengungkapan CSR bagi perusahaan bersifat penting karena stakeholder perlu menevaluasi dan mengetahui sejumlah mana perusahaan melaksankan perannya sesuai keinginan stakeholder.

\section{Teori Legitimasi}

O’Donovan (dalam Hadi 2010:87) berpendapat legitimasi organisasi dapat dilihat sebagai sesuatu yang diberikan masyarakat kepada perusahaan dari sesuatu yang diinginkan atau dicari perusahaan dari masyarakat. Ghozali dan Chariri (2007) mengatakan bahwa kegiatan perusahaan dapat menimbulkan dampak sosial dan 
lingkungan, sehingga praktik pengungkapan sosial dan lingkungan merupakan alat manajerial yang digunakan perusahaan untuk menghindari konflik sosial dan lingkungan. Teori tersebut dibutuhkan oleh institusi-institusi untuk mencapai tujuan agar kongruen dengan masyarakat luas. Teori legitimasi menganjurkan perusahaan untuk meyakinkan bahwa aktivitas dan kinerjanya dapat diterima oleh masyarakat.

\section{Teori Pensinyalan}

Teori sinyal adalah teori yang menjelaskan mengapa perusahaan mempunyai dorongan untuk memberikan informasi laporan keuangan pada pihak ekternal (Sari dan Zuhrotun, 2006). Dorongan perusahaan untuk memberikan informasi adalah untuk memberikan informasi karena terdapat asimetri informasi antara perusahaan dan pihak luar karena perusahaan mengetahui lebih banyak mengenai perusahaan dan prospek yang akan datang daripada pihak luar (investor dan kreditur).teori pensinyalan mengemukakan tentang bagaimana seharusnya sebuah perusahaan memberikan sinyal pengguna laporan keuangan. Laporan keuangan dianggap sangat baik dalam mengungkapkan informasi keuangan perusahaan yang menjadi sinyak bahwa perusahaan memiliki masa depan yang baik sehingga investor tertarik untuk berinvestasi pada perusahaan (Shape, 1997).

\section{Triple Bottom Line}

Konsep Triple Bottom Line mengimplikasikan bahwa perusahaan harus lebih mengutamakan stakeholder (semua pihak yang terlibat dan tekena dampak dari kegiatan yang dilakukan perusahaan daripada kepentingan shareholder (pemegang saham). Aspek yang terdapat dalam Triple Bottom Line meliputi 1) Profit, merupakan unsur terpenting dan menjadi tujuan utama dari setiap kegiatan usaha, 2) People, merupakan stakeholder penting bagi peusahaan karena dukungan masyarakat sekitar sangat diperlukan, 3)Planet, jika perusahaan ingin tetap eksis maka harus disertakan pula tanggung jawab kepada lingkungan, karena lingkungan adalah sesuatu yang terkait dengan seluruh bidang kehidupan kita.

\section{Corporate Social Responsibility}

CSR merupakan salah satu bentuk tanggung jawab sosial yang diberikan perusahaan dengan tujuan untuk meningkatkan nilai komersial perusahaan dengan tanpa meninggalkan nilai etika untuk kualitas lingkungan dan masyarakat berdasarkan 3P (profit, people dan planet). Tujuan dari CSR adalah untuk meningkatkan citra perusahaan dan mempertahankannya di mata masyarakat secara implisit, dengan asumsi bahwa perilaku perusahaan secara fundamental adalah baik. Selain itu CSR juga memberikan informasi kepada investor untuk membebaskan akuntabilitas organisasi atas adasar asumsi adanya kontrak sosial di antara organisasi dan masyarakat. 
Pengungkapan Corporate Social Responsibility

Perusahaan selain menerapkan CSR juga perlu melakukan pengungkapan (disclosure) atas aktivitas CSR yang dilakukan kepada stakeholder. Penerapan CSR adalah suatu aktivitas yang dilakukan perusahaan untuk menerapkan kegaiatan CSR, sedangkan pengungkapan merupakan langkah akhir dalam proses akuntansi, yaitu penyajian informasi dalam bentuk statemen keuangan. Tujuan pengungkapan CSR adalah untuk menyediakan informasi yang relevan kepada pemakai lapora keuangan untuk membenatu mereka mengambil keputusan dengan cara terbaik yang mungkin dengan pembatasan bahwa manfaatnya harus melebihi dari biayanya.

\section{Leverage}

Leverage adalah salah satu alat yang digunakan untuk mengukur tingkat ketergantungan perusahaan terhadap kreditur untuk membiayai aset perusahaan. Tingkat leverage merupakan salah satu ukuran kinerja keuangan yang mengukur kemampuan perusahaan dalam memenuhi semua kewajibannya kepada pihak lain. Fahmi (2011:61) menjelaskan bahwa leverage sering diartikan sebagai pendongkrak kinerja perusahaan dan identik dengan hutang, leverage sendiri merupakan kemampuan perusahaan untuk memenuhi kewajiban finansialnya.

DER $=\frac{\text { Total Hutang }}{\text { Total Ekuitas }}$

\section{Profitabilitas}

Profitabilitas dapat diartikan sebagai kemampuan perusahaan untuk menghasilkan laba. Profitabilitas merupakan alat yang digunkan untuk menganalisis kinerja manajemen, tingkat profitabilitas akan menggambarkan posisi laba perusahaan. Rasio profitabilias merupakan rasio untuk menilai kemampuan perusahaan dalam mencari keuntungan. Rasio ini juga memberikan ukuran tingkat efektivitas manajemen suatu perusahaan.

ROA $=\frac{\text { Laba Bersih setelah Pajak }}{\text { Total Aset }}$

\section{Company Size}

Ukuran perusahaan biasa digunakan untuk menentukan besar kecilnya suatu perusahaan, perusahaan yang lebih besar akan lebih bertahan daripada perusahaan yang lebih kecil karena semakin besar perusahaan maka semakin besar sumber daya yang digunakan oleh perusahaan tersebut. Dengan sumber daya yang besar tersebut perlu menyediakan informasi untuk keperluan internal dimana informasi tersebut sekaligus menjadi bahan untuk keperluan pengungkapan informasi kepada pihak ekternal.

SIZE $=\log ($ Total Aset $)$ 


\section{Hipotesis}

H1: Leverage, Profitabilitas dan Company Size secara simultan berpengaruh terhadap Pengungkapan Corporate Social Responsibility.

$\mathrm{H} 2$ : Leverage, Profitabilitas dan Company Size secara parsial berpengaruh terhadap Pengungkapan Corporate Social Responsibility.

\section{METODE PENELITIAN}

\section{Teknik Pengambilan Sampel}

Populasi dalam penelitian ini adalah perusahaan Food and Beverages yang terdaftar di BEI periode 2016-2018 sebanyak 16 perusahaan. Teknik pengambilan sampel yang digunakan dalam penelitian ini adalah purposive sampling. Kriteria sampel dalam penelitian sebagai berikut:

1. Perusahaan Food and Beverages yang terdaftar di BEI periode 2016-2018

2. Perusahaan yang mempublikasikan laporan keuangan dan laporan tahunannya secara lengkap sesuai dengan data yang dibutuhkan variabel penelitian

3. Perusahaan yang mengungkapkan tanggung jawab sosial perusahaan dalam laporan tahunan.

\section{Teknik Pengumpulan Data}

Teknik pengumpulan data yang digunakan dalam penelitian adalah teknik dokumentasi. Teknik dokumentasi dalam penelitian ini menggunakan data sekunder perusahaan yang akan menjadi sampel penelitian dan data laporan tahunan perusahaan. Sumber data yang digunakan dalam penelitian ini adalah data kuantitatif dimana data kuantitatif yang berupa angka ini diperoleh dari perusahaan Food and Beverages yang terdaftar di BEI.

\section{HASIL DAN PEMBAHASAN}

Berdasarkan teknik penentuan sampel yang digunakan maka diperoleh 16 perusahaan makanan dan minuman yang memenuhi kriteria selama periode 20162018. Dengan demikian banyaknya sampel yang diperoleh adalah 48 sampel.

Indek pengungkapan CSR merupakan konsep dimana perusahaan mempertimbangkan dampak aktifitas mereka terhadap pelanggan, pemasok dan stakeholder yang lan seperti lingkungan. Dilihat dari nilai rata-rata sebsar 0,0992, std deviasi 0,06374. Standar deviasi menunjukkan lebih kecil dari nilai rata-rata, bila nilai standar deviasi lebih kecil artinya data digunakan mengelompok di seputar nilai rata- ratanya, sehingga tidak menunjukkan variasi yang banyak dan penyimpanannya kecil dengan penyimpangan maksimal 0,06374. Nilai minimum untuk variabel leverage sebesar 0,09, nilai maksimum sebesar 2,23, nilai rata-rata hitung (mean) sebesar 0,90 dengan standar deviasi sebessar 0,55. Variabel Profitabilitas memiliki nilai maksimum 0,53 , nilai minimum 0,00 , nilai rata-rata 0,0985 dan standar deviasi sebesar 0,55015. Variabel Company Size mempunyai nilai minimum sebesar 5,89, nilai maksimum sebesar 13,66, nilai rata-rata sebesar 10,18 dan standar deviasi sebesar 2,68 (Tabel 1). 
Alfia Rizqi Aprillia dkk., Pengaruh Leverage, Profitabilitas

\begin{tabular}{lrrrrr}
\hline \multicolumn{6}{l}{ Tabel 1. Analisis Statistik Deskriptif } \\
\hline N & \multicolumn{1}{l}{ Minimum } & Maximum & Mean & Std. Deviation \\
\hline CSR & 48 &, 01 &, 24 &, 0992 &, 06374 \\
LEVERAGE & 48 &, 09 & 2,23 &, 9033 &, 55015 \\
PROFITABILITAS & 48 &, 00 &, 53 &, 0985 &, 11078 \\
COMPANY SIZE & 48 & 5,89 & 13,66 & 10,1844 & 2,68236 \\
Valid N (listwise) & 48 & & & & \\
\hline
\end{tabular}

Sumber: Hasil Olahan SPSS 25

Tabel 2. Uji Normalitas

\begin{tabular}{llr}
\hline & & Unstandardizes Residual \\
\hline $\mathrm{N}$ & & 48 \\
Normal Parameters & a,b &, 0000000 \\
& Std. Deviation &, 05759533 \\
Most Extreme Differences & Absolute &, 137 \\
& Positive &, 137 \\
& Negative &,- 095 \\
Test Statistic & &, 137 \\
Asymp. Sig. (2-tailed) & &, $024^{\mathrm{c}}$ \\
\hline
\end{tabular}

a. Test distribution is Normal

b. Calculated from data

c. Lilliefors Significance Correction

Sumber: Hasil Olahan SPSS 25

Tabel 3. Uji Multikolinieritas

\begin{tabular}{lcc}
\hline \multirow{2}{*}{$\begin{array}{l}\text { Model } \\
\text { (Constant) }\end{array}$} & \multicolumn{2}{c}{ Tollinearity Statistics } \\
\hline LEVERAGE & & VIF \\
PROFITABILITAS & .994 & 1,006 \\
COMPANY SIZE & .850 & 1,176 \\
a. Dependemt Variable: CSR & .852 & 1,173 \\
\hline
\end{tabular}

Sumber: Hasil Olahan SPSS 25

\section{Uji Asumsi Klasik}

Berdasarkan tabel 2 diketahui bahwa uji statistic non-parametrik KolomogorovSmirnov menunjukkan nilai Kolomogrov-Smirnov sebesar 0,137 dan Nilai Asymp Sig (2- tailed) sebesar 0,024 yang menunjukkan lebih besar dari 0,05, maka dapat dinyatakan bahwa residual berdistribusi normal (Tabel 2).

Berdasarkan Tabel 3 diatas, dapat dilihat bahwa nilai tolerance ketiga variabel lebih dari 0,10 dan nilai VIF kurang dari 10. Maka dapat disimpulkan bahwa tidak terjadi masalah multikolinieritas pada model regresi. 
Alfia Rizqi Aprillia dkk., Pengaruh Leverage, Profitabilitas

Tabel 4. Uji Autokorelasi

\begin{tabular}{|c|c|c|c|c|c|}
\hline Model & $\mathrm{R}$ & R Square & $\begin{array}{c}\text { Adjusted R } \\
\text { Square }\end{array}$ & $\begin{array}{l}\text { Std. Error of } \\
\text { the Estimate }\end{array}$ & Durbin-Watson \\
\hline 1 &, $428^{a}$ &, 184 & , 128 & 05953 & 2,093 \\
\hline
\end{tabular}

Sumber: Hasil Olahan SPSS 25

Tabel 5. Hasil Uji Regresi Linier Berganda

$\begin{array}{cc}\text { Unstandardized } & \text { Standarized } \\ \text { Coefficients } & \text { Coefficients }\end{array}$

Std.

\begin{tabular}{lrrrrc}
\multicolumn{1}{c}{ Model } & \multicolumn{1}{c}{ B } & \multicolumn{1}{c}{ Error } & \multicolumn{1}{c}{ Beta } & \multicolumn{1}{c}{ t } & \multicolumn{1}{c}{ Sig. } \\
\hline (Constant) & .187 & .044 & & 4,257 & .000 \\
LEVERAGE &.-145 & .016 &.-393 & $-2,873$ & .006 \\
PROFITABILITAS &.-122 & .085 &.-211 & $-1,43$ & .160 \\
COMPANY SIZE &.-003 & .004 &.-143 &.-969 & .338 \\
\hline
\end{tabular}

Sumber: Hasil Olahan SPSS 25

Berdasarkan Tabel 4, dapat diketahui hasil uji autokerelasi yang menunjukkan nilai Durbin Watson hitung sebesar 2,093. Penelitian ini menggunakan data sejumlah 48 dan variabel independen sebanyak 3 sehingga berdasarkan tabel Durbin Watson diketahui nilai $\mathrm{dL}=0,8572$ dan $\mathrm{dU}=1,7277$ (pada tabel DW). Nilai 2,093 tersebut lebih besar dari nilai dU maka dapat disimpulkan bahwa dalam model regresi tidak terdapat masalah autokorelasi.

\section{Regresi Linier Berganda}

Berdasarkan Tabel 5, maka diperoleh persamaan regresi linier berganda pada penelitian ini sebagai berikut :

$\mathrm{CSRI}=\alpha+\beta 1 \mathrm{LEV}+\beta 2 \mathrm{PROF}+\beta 3 \mathrm{SIZE}+\mathrm{e}$

$\mathrm{CSRI}=0,187-0,45 \mathrm{LEV}-0,122 \mathrm{PROF}-0,003 \mathrm{SIZE}+\mathrm{e}$

Dari persamaan regresi diatas dapat diinterpretasikan sebagai berikut:

a. Konstanta $(\alpha)$

Nilai konstanta sebesar 0,187 menunjukkan apabila variabel bebas leverage, profitabilitas, dan company size tidak memberikan pengaruh, maka diprediksikan nilai pengungkapan CSR pada perusahaan sampel selama periode pengamatan adalah sebesar 0,187 .

b. Nilai koefisien regresi ( $\beta 1)$ leverage sebesar $-0,045$ menunjukkan arah hubungan negatif antara leverage dengan CSR. Tanda negatif menunjukkan pengaruh leverage tidak searah terhadap CSR.

c. Nilai koefisien regresi $(\beta 2)$ profitabilitas sebesar $-0,122$ menunjukkan arah hubungan negatif antara profitabilitas dengan CSR. Tanda negatif menunjukkan pengaruh profitabilitas tidak searah terhadap CSR. 
d. Nilai koefisien regresi ( $\beta 3$ ) company size sebesar $-0,003$ menunjukkan arah hubungan negatif antara company size dengan CSR. Tanda negatif menunjukkan pengaruh company size tidak searah terhadap CSR.

\section{Hasil Pengujian Hipotesis}

\section{Uji F}

Berdasarkan Tabel 6, menunjukkan bahwa nilai F hitung sebesar 3,298 dengan nilai siginifikan sebesar 0,029 lebih kecil dari $\alpha(0,05)$. Maka dapat disimpulkan bahwa Leverage, Profitabilitas dan Company Size secara bersama-sama berpengaruh signifikan terhadap Pengungkapan CSR.

\section{Uji t}

Variabel Leverage menunjukkan nilai signifikan 0,006 lebih kecil dari 0,05. Sehingga dapat disimpulkan bahwa Leverage berpengaruh signifikan terhadap Pengungkapan CSR. Variabel Profitabilitas menunjukkan nilai signifikan 0,160 lebih besar dari 0,05. Maka dapat disimpulkan bahwa Profitabilitas tidak berpengaruh secara signifikan terhadap Pengungkapan CSR. Variabel Company Size menunjukkan nilai signifikansi 0,338 lebih besar dari 0,05. Maka dapat disimpulkan bahwa Company Size tidak berpengaruh secara signifikan terhadap Pengungkapan CSR (Tabel 7).

Tabel 6. Uji F

\begin{tabular}{llrcrcr}
\hline & Model & Sum of Squares & Df & Mean Square & F & Sig. \\
\hline 1 & Regression &, 035 & 3 &, 012 & 3,298 & $.029^{\mathrm{b}}$ \\
Residual &, 156 & 44 &, 004 & & \\
Total &, 191 & 47 & & & \\
\hline
\end{tabular}

Sumber: Hasil Olahan SPSS 25

Tabel 7. Uji t

\begin{tabular}{|c|c|c|c|c|c|}
\hline \multirow{3}{*}{ Model } & \multirow{2}{*}{\multicolumn{2}{|c|}{$\begin{array}{l}\text { Unstandardized } \\
\text { Coefficients }\end{array}$}} & \multirow{3}{*}{$\begin{array}{c}\begin{array}{c}\text { Standarized } \\
\text { Coefficients }\end{array} \\
\text { Beta }\end{array}$} & \multirow{3}{*}{$\mathrm{t}$} & \multirow{3}{*}{ Sig. } \\
\hline & & & & & \\
\hline & B & $\begin{array}{l}\text { Std. } \\
\text { Error }\end{array}$ & & & \\
\hline (Constant) & .187 & .044 & & 4,257 & .000 \\
\hline LEVERAGE & -145 & .016 &.-393 & $\begin{array}{c}- \\
2,873\end{array}$ & .006 \\
\hline PROFITABILITAS &.-122 & .085 &.-211 & $-1,43$ & .160 \\
\hline COMPANY SIZE & .-003 & .004 &.-143 &.-969 & .338 \\
\hline
\end{tabular}

Sumber: Hasil Olahan SPSS 25

Tabel 8. Koefisien Determinasi (R2)

\begin{tabular}{clccc} 
Modal & $\mathrm{R}$ & $\mathrm{R}$ Square & Adjusted R Square & Std. Error of the Estimate \\
\hline 1 &, 428 &, 184 &, 128 &, 05953
\end{tabular}

Sumber: Hasil Olahan SPSS 25 


\section{Koefisien Determinasi (R2)}

Berdasarkan Tabel 8, dapat diketahui bahwa nilai koefisien determinasi yang terletak pada kolom R Square sebesar 0,184. Artinya sebesar 18,40 \% variabel independen yang terdiri dari leverage, profitabiltas, dan company size dapat menjelaskan variabel dependen yaitu Corporate Social Responsibility sedangkan sisanya yaitu $81,60 \%$ dijelaskan oleh variabel lain diluar variabel dalam penelitian.

\section{SIMPULAN}

Berdasarkan hasil penelitian yang telah dilakukan dapat diambil kesimpulan bahwa secara parsial leverage berpengaruh terhadap pengungkapan CSR, sedangkan profitabilitas dan company size tidak berpengaruh terhadap pengungkapan CSR. Hasil Uji F menunjukkan bahwa secara simultan leverage, profitabilas dan company size secara bersama-sama berpengaruh terhadap pengungkapan CSR. Berdasaran hasil penelitian dan pembahsan sebelumya dapat ditarik saran sebagai berikut, bagi perusahaan diharapkan mengungkapkan kegiatan yang berhubungan dengan tanggung jawab sosial dengan lebih lengkap sejalan dengan operasi usahanya, mengingat perusahaan adalah bagian dari masyarakat. Pihak manajemen sebaiknya memiliki tingkat kesadaran yang tinggi akan pentingnya pengungkapan tanggung jawab sosial. Karena tinggi rendahnya profit atau besar kecilnya perusahaan tergantung dari tingkat kesadaran manjemen dalam mengungkapkan tanggung jawab sosialnya

\section{DAFTAR PUSTAKA}

Dyah, Gusti Ayu dan Putra, Ida Bagus 2015, Pengaruh Profitabilitas, Ukuran Perusahaan dan Kepemilikan Saham Publik terhadap Pengungkapan CSR, E-Jurnal Akuntansi, Universitas Udayana, Bali.

Felisia, Amelia Limijaya 2014, Triple Bottom Line dan Sustainabilty, Jurnal Vo.18 No.1, Universitas Katolik Parahayang, Bandung

Indahwati, Tricia Yuli 2016, Pengaruh Leverage, Profitabilitas dan Company Size terhadap Pengungkapan Corporate Social Responsibility pada Perusahaan Property, Real Estate dan Building Construction yang terdaftar di BEI, Skripsi, Universitas Airlangga, Surabaya.

Purwanto, Agus 2011, Pengaruh Tipe Industri, Ukuran Perusahaan dan Profitabilitas terhadap Corporate Social Responsibility, Jurnal Akuntansi dan Auditing, Vol.8 No.1, Universitas Diponegoro, Semarang. 
Putri, Rafika Anggraeni dan Chritiawan, Yulius Jogi 2014, Pengaruh Profitabilitas, Likuiditas dan Leverage terhadap Pengungkapan Corporate Social Responsibility pada perusahaan yang mendapat penghargaan ISRA dan Listed di BEI periode 2010-2012, Jurnal, Universitas Kristen Petra, Surabaya

Saputra, Syailendra Putra 2016, Pengaruh Leverage, Profitabilitas dan Size terhadap Pengungkapan CSR yang terdaftar di BEI, Journal of Economic and Economic Education Vol.5 No.1 (75-89), STKIP PGRI Sumbar, Sumatera Barat.

Vivie, Fathia, Zirman dan Anisma, Yuneita 2014, Pengaruh Profitabilitas, Leverage, Porsi Kepeilikan Saham Publik dan Ukuran Dewan Komisaris Terhadap Pengungkapan CSR dalam Laporan Tahunan Perusahan Food and Beverages yang Listing di Bursa Efek Indonesia, Jurnal JOM Fekon Vol.1 No.2, Universitas Riau, Pekanbaru.

Wulandari, Sari dan Zulhaimi, Hanifa 2017, Pengaruh Proftabilitas terhadap CSR pada Perusahaan Manufaktur dan Jasa yang terdaftar di BEI, Jurnal Riset Akuntansi \& Keuangan, 5 (1), 1477-1488, Universitas Pendidikan Indonesia, Bandung. Website : www.idx.co.id. 